\title{
Impact of vaccination on the reproductive performance of multiparous Nellore cows ${ }^{1}$
}

\author{
Luiz C.L. Ferreira ${ }^{2}$, Henrique J. Fernandes ${ }^{3}$, Aline G. Silva ${ }^{4}$, Carlos E. Fernandes ${ }^{5}$, \\ Iveraldo S. Dutra ${ }^{6}$, Rayane C. Pupin ${ }^{7}$ and Ricardo A.A. Lemos ${ }^{7 *}$
}

\begin{abstract}
Ferreira L.C.L., Fernandes H.J., Silva A.G., Fernandes C.E., Dutra I.S. \& Lemos R.A.A. 2018. Impact of vaccination on the reproductive performance of multiparous Nellore cows. Pesquisa Veterinária Brasileira 38(3):456-461. Departamento de Medicina Veterinária, Faculdade de Medicina Veterinária e Zootecnia, Universidade Federal de Mato Grosso do Sul, Av. Senador Filinto Müller 2443, Campo Grande, MS 79070-900, Brazil. E-mail: ricardo.lemos@ufms.br

Two experiments were conducted to evaluate the impact of two vaccines on the reproductive performance of multiparous beef cows in Mato Grosso do Sul, Midwest Brazil. In Experiment 1,765 calved multiparous Nellore cows were subjected to the same fixed-time artificial insemination (FTAI) protocol and rebred. Ultrasound pregnancy diagnosis was performed 30 and 90 days post-FTAI (DPI). Rates of pregnancy and pregnancy loss were determined for three periods: from 30 to 90 DPI, from 30 DPI to calving, and from 90 DPI to calving. The cows were assigned to three groups with different vaccination protocols namely, Group VACMULT ( $n=250)$ : vaccine against bovine herpesvirus 1 (BoHV-1), bovine viral diarrhea virus (BVDV), and leptospirosis; Group VACL $(n=245)$ : vaccine against leptospirosis alone; Group NOVAC $(n=270)$ : no vaccination. Serum antibody titers for BoHV-1, BVDV, and leptospirosis, measured in 57 cows from each group indicated active infection, suggesting circulation of these pathogens in the herd. No differences in pregnancy rates were observed across groups. Pregnancy loss rates did not differ significantly across groups within any of the periods investigated (30 to 90 DPI, 30 DPI to calving, or 90 DPI to calving). In Experiment 2, two vaccination protocols for each vaccine were investigated. Group VACGEST was vaccinated on day zero of FTAI (D0) and again 30 days post-FTAI (30 DPI). Group VACPREV was vaccinated on D0 and again on the day of insemination (D11). No significant difference was observed between groups, or significant gestational loss in the group that received the second vaccine on the day of insemination. The results revealed that neither vaccine interfered with the reproductive performance of multiparous cows. No differences were observed between vaccination carried out on both D0 and D11 and that performed on both D0 and D30. The performance of the IBR/BVDV/Leptospirosis vaccine on the day of the artificial insemination did not cause adverse effects on the reproductive parameters.
\end{abstract}

INDEX TERMS: Vaccination, reproduction, performance, Nellore cows, cattle, reproductive diseases.

\footnotetext{
${ }^{1}$ Received on May 15, 2017.

Accepted for publication on May 29, 2017.

Part of the doctoral thesis of the first author.

${ }^{2}$ Veterinary practicioner, Rua Inácio Gomes 108, Campo Grande, MS 79041-231, Brasil.

${ }^{3}$ Programa de Graduação em Zootecnia, Universidade Estadual de Mato Grosso do Sul, Unidade Universitária de Aquidauana, Rodovia Aquidauana CERA, Aquidauana, MS 79200-000, Brasil.

${ }^{4}$ Departamento de Zootecnia, Universidade Federal de Viçosa, Viçosa, MG 36570-900, Brasil.
}

\footnotetext{
${ }^{5}$ Centro de Ciências Biológicas e de Saúde, Universidade Federal de Mato Grosso do Sul (UFMS), Av. Filinto Müller 2443, Campo Grande, MS 79074-460, Brasil.

${ }^{6}$ Departamento de Apoio, Produção e Saúde Animal, Faculdade de Medicina Veterinária, Universidade Estadual Paulista (Unesp), Rua Clóvis Pestana 793, Araçatuba, SP 16050-680, Brasil.

${ }^{7}$ Laboratório de Patologia Animal, Faculdade de Medicina Veterinária e Zootecnia, Universidade Federal de Mato Grosso do Sul, Av. Filinto Müller 2443, Campo Grande, MS 79074-460, Brasil. *Corresponding author: ricardo.lemos@ufms.br
} 
RESUMO.- [Impacto da vacinação sobre o desempenho reprodutivo de vacas Nelore multíparas] Foram delineados dois experimentos para avaliar o impacto de duas vacinas no desempenho reprodutivo de vacas multíparas de bovinos de corte em Mato Grosso do Sul, Centro-Oeste do Brasil. No Experimento 1 foram utilizadas 765 vacas multíparas paridas da raça Nelore submetidas ao mesmo protocolo de inseminação artificial em tempo fixo (IATF) e repassadas por touros. 0 diagnóstico de gestação por ultrassonografia foi realizado aos 30 e 90 dias pós IATF. A prenhez e a taxa de perda de gestação foram determinadas para três períodos: de 30 a 90 DPI, de 30 DPI até para o parto e de $90 \mathrm{DPI}$ até o parto. As vacas foram distribuídas em três grupos: grupo VACMULT $(n=250)$, vacinado com vacina contra herpesvírus bovino tipo 1 (BoHV-1), vírus da diarreia viral bovina (BVDV) e leptospirose; grupo VACL $(n=245)$, vacinado somente contra leptospirose; e grupo NOVAC $(n=270)$, não vacinado. Títulos de anticorpos no soro de 57 vacas de cada grupo evidenciaram infecção por BoHV-1, BVDV e leptospirose, sugerindo circulação desses patógenos no rebanho. No diagnóstico por ultrassonografia, a prenhez não diferiu em nenhum dos três grupos. A taxa de perda de gestação não diferiu significantemente entre os grupos e dentro de qualquer um dos períodos investigados ( 30 a 90 DPI, 30 DPI até o parto ou 90 DPI até o parto). No Experimento 2 foram testados dois protocolos de vacinação usando as vacinas contra IBR/BVDV/leptospirose e somente contra leptospirose em ambos. No grupo VACGEST as vacas foram vacinas no dia zero (D0) do protocolo da IATF e 30 dias pós- IATF (30 DPI). No grupo VACPREV a primeira dose foi administrada no D0 e a segunda no mesmo dia da IATF (D11). Não houve diferença significativa entre os grupos, nem perda gestacional significativa no grupo que recebeu a segunda vacina no dia da inseminação (VACPREV). Os resultados mostram que as vacinas contra IBR/BVDV/leptospirose e somente contra leptospirose não interferiram no desempenho reprodutivo de vacas multíparas. Não houve diferença significativa entre o protocolo de vacinação empregado em D0 e D11 e aquele utilizado em D0 e 30 DPI. A realização da vacina contra IBR/BVD/leptospirose no dia da inseminação artificial não provocou efeitos adversos nos parâmetros reprodutivos.

TERMOS DE INDEXAÇÃO: Vacinação, reprodução, vacas Nelore multíparas, doenças reprodutivas, bovinos.

\section{INTRODUCTION}

Losses caused by embryonic or fetal death have a considerable impact on fertility rates in beef cattle production systems (Santos et al. 2004, Junqueira et al. 2006, Aono et al. 2013, Pereira et al. 2013). In most cases, the causes of these losses remain undetermined (Corbellini et al. 2006, Antoniassi et al. 2013). There are no conclusive studies on the efficiency of vaccination against IBR/BVDV/Leptospirosis in the prevention of reproductive losses caused by these diseases in cattle. In addition, there is concern that modified live vaccines may cause fetal losses, so decision-making on whether or not vaccination should be carried out is an important dilemma for practicing veterinarians working in the field (Cortese 2015).
Given the difficulties establishing a conclusive diagnosis for reproductive losses, many veterinarians and ranchers, relying on serological evidence, vaccinate cattle against diseases that affect reproductive performance as a preventive measure to reduce reproductive losses (Aono et al. 2013). Among these vaccines are those against leptospirosis, bovine viral diarrhea virus (BVDV), and infectious bovine rhinotracheitis virus (BoHV-1). However, the practicing veterinarians resist to the notion of vaccinating cows in the same day of artificial insemination arguing that this practice could possibly cause pregnancy loss. The purpose of this study was to evaluate the impact of two vaccines and two vaccination protocols on the reproductive performance of primo-vaccinated multiparous beef cows.

\section{MATERIALS AND METHODS}

The study was conducted in an extensive cattle-raising farm ( 5000 ha; Nellore beef cattle) located in Miranda, Mato Grosso do Sul state, Brazil (20 $\left.24^{\prime} 26^{\prime \prime} \mathrm{S} ; 56^{\circ} 22^{\prime} 42^{\prime \prime} \mathrm{W}\right)$ and approved by the Ethics Committee of UFMS under the protocol number 702/2015. The study design comprised two experiments.

Experiment 1. In this experiment, 765 calved multiparous Nellore cows 30-60 post-partum were subjected to the same fixed-time artificial insemination (FTAI) protocol from November 2011 to January 2012. All cows were treated with the same FTAI protocol (Fig.1). On day 0 (D0), the cows received $2 \mathrm{mg}$ of estradiol benzoate (EB) and had an intravaginal device inserted containing $1.9 \mathrm{~g}$ of progesterone (P4), which remained in situ for nine days. On D9, $12.5 \mathrm{mg}$ of dinoprost tromethamine (DT) was injected, the intravaginal device removed, and $1 \mathrm{mg}$ of estradiol cypionate (EC) administered with $300 \mathrm{IU}$ of equine chorionic gonadotrophin (eCG; Novormon ${ }^{\circledR}$ ). On D11, all cows were inseminated with semen from the same bull. The procedures were conducted by the same two technicians. Cows were in Brachiaria brizantha pasture, with water and mineral supplementation ad libitum; they were in good

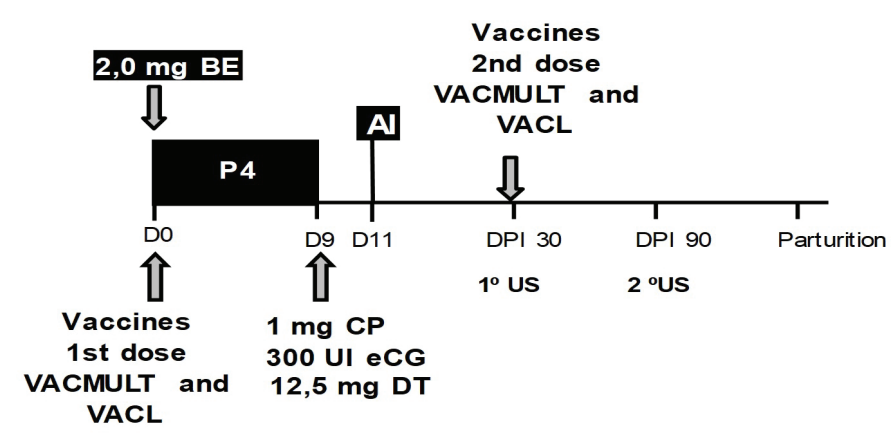

Fig.1. Experimental design of FTAI vaccination protocols in Experiment 1. FTAI = fixed-time artificial insemination, P4 = intravaginal device containing $1.9 \mathrm{mg}$ of progesterone, $\mathrm{DPI}=$ days post-insemination, $\mathrm{BE}=$ estradiol benzoate, $\mathrm{AI}=$ artificial insemination, VACMULT = vaccine against bovine herpesvirus 1, bovine viral diarrhea virus and leptospirosis, VACL = vaccine against leptospirosis alone, $\mathrm{CP}=$ estradiol cipionate, $\mathrm{UI}=$ international unity, $\mathrm{eCG}=$ equine chorionic gonadotrophin, $\mathrm{DT}=$ tromethamine dinoprost, US = ultrasonography. 
nutritional condition with a body score of $3.85 \pm 0.5$ estimated accordingly to previous publication (Wagner et al. 1988). Sixteen days later, all cows were replaced with bulls until the end of the breeding season.

The pregnancy diagnosis was done by ultrasonography at 30 and 90 days after insemination (Fig.1). Any cow detected pregnant at 30 days after insemination and then bare at 90 days of insemination was considered as having lost the concept (Curran et al. 1986). With the results obtained from ultrasonography the pregnancy and pregnancy loss rates were determined from 30 to 90 days, from 30 days to deliverance and from 90 to deliverance.

At the beginning of the trial, the cows were randomly assigned to one of three groups (Fig.1). Group VACMULT $(n=250)$ received vaccine against BoHV-1, BVDV and leptospirosis (caused by Leptospira canicola, L. grippotyphosa, L. hardjo, L. icterohaemorrhagiae, and L. pomona $)^{8}$. Group VACL $(n=245)$ was vaccinated against leptospirosis alone (same Leptospira species listed above). Group NOVAC $(n=270)$ received no vaccine and were the control group. In all three groups, the cows were naïve to these vaccines. None of the cows from any of those groups was previously vaccinated with the vaccines used in the experiments.

All the cows in this experiment had previously been vaccinated against foot-and-mouth disease in November 2011, in compliance with sanitary regulations of Mato Grosso do Sul state, after an outbreak of the disease in neighboring Paraguay. This herd is free from brucellosis; the cows are only vaccinated against foot and mouth disease and anthelmintic medication. On D0, blood was sampled from 57 cows randomly selected from each group, and tested for agglutination (leptospirosis) and neutralization (BoHV1 and BVDV) ${ }^{9}$. Cut-off points for positive serology were $>100$ for leptospirosis, >8 for BoHV-1, and >16 for BVDV (Aono et al. 2013, Pereira et al. 2013).

Experiment 2. The effect of vaccination protocols on the reproductive performance of cows subjected to FTAI was evaluated as follows (Fig.2). Protocol VACGEST, recommended by the manufacturer, was adopted as the control and protocol VACPREV, devised in-house, sought to enhance protection in early pregnancy. Only multiparous cows that calved as a result of the FTAI program from November 2011 and January 2012 were included in this experiment.

In both protocols vaccines against BoHV-1, BVDV and leptospirosis $(n=50$ VACGEST and $n=51$ VACPREV) and only against leptospirosis ( $n=49$ VACGEST and $n=47$ VACPREV) were used. In the VACGEST protocol the cows were vaccinated on D0 of the FTAI and a second dose was applied 30 days after the artificial insemination (D30); while in the VACPREV protocol the first dose was applied on D) and the second in the day of artificial insemination (D11). All cows of this experiment were vaccinated against foot and mouth disease during the period from insemination to D30.

For both experiments the rates of pregnancy and pregnancy loss were analyzed using a logit regression with random intercept,

8 Zoetis Indústria de Produtos Veterinários Ltda., Rua Luiz Fernando Rodrigues 1701, Campinas, SP 13064-798, Brazil.

9 The tests were performed at the Laboratory of Leptospirosis and Laboratory of Animal Virology, Department of Preventive Veterinary Medicine, Universidade Estadual de Londrina, Londrina, PR, Brazil.

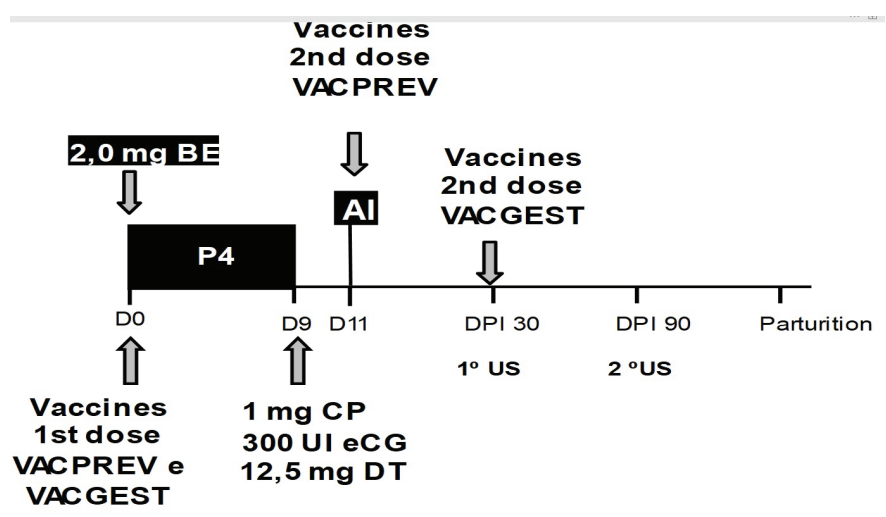

Fig.2. Experimental design of FTAI vaccination protocols in Experiment 2. FTAI = fixed-time artificial insemination, P4 = intravaginal device containing $1.9 \mathrm{mg}$ of progesterone, DPI = days post-insemination, $\mathrm{BE}=$ estradiol benzoate, $\mathrm{AI}=$ artificial insemination, $\mathrm{VACPREV}=$ vaccinated on $\mathrm{D} 0$ and again on the day of insemination, VACGEST = as vaccinated on day zero of FTAI (D0) and again 30 days post-FTAI, $\mathrm{CP}=$ estradiol cipionate, $\mathrm{UI}=$ international unity, $\mathrm{eCG}=$ equine chorionic gonadotrophin, DT = tromethamine dinoprost, US = ultrasonography.

using the GLIMMIX procedure (with Satterthwaite approximation to determine the denominator degrees of freedom for tests of fixed effects) (SAS software v. 9.4) ${ }^{10}$. The LSMEANS statement (with ilink and pdiff options) was used to predict and compare treatment means. Cow was used as the experimental unit and the model comprised the fixed effects of body condition score, vaccine or protocol, and the random effect of group. For all statistical analyses, significance was set at $p<0.05$ and tendencies were declared if $0.05<p<0.10$.

\section{RESULTS}

Infection rates of $49.4 \%, 88.3 \%$, and $90.0 \%$ were found for BoHV-1, BVDV, and leptospirosis, respectively (Table 1). The serological profile was also compared with the results of other studies (Table 2).

The pregnancy losses that occurred in vaccinated and non-vaccinated groups are presented in Table 3. At 30 and 90 DPI, pregnancy rates did not differ significantly $(p>0.05)$ between VACMULT, VACL and NOVAC groups, nor did pregnancy loss rates from 30 and 90 until the birth date. DPI.

The results from a comparison between two vaccination protocols considering the percentage of pregnancy and pregnancy loss in cows vaccinated against BoHV-1, BVDV and leptospirosis (Experiment 2) are on Table 4. There were also no significant difference $(p>0.05)$ in rate of pregnancy at 30,90 or $120 \mathrm{DPI}$, calving rate, or gestational losses between the gestational diagnoses performed at 30 and 90 DPI and the calving day.

10 SAS Institute Inc., Cary, NC, USA. 
Table 1. Percent of serum samples from cows containing antibodies against BoHV-1 ${ }^{\mathrm{a}}, \mathrm{BVDV}^{\mathrm{b}}$ and Leptospira hardjo

\begin{tabular}{|c|c|c|c|}
\hline Pathogen & Titer & Number of cows & $\%$ \\
\hline \multirow[t]{4}{*}{ BoHV-1 } & Negative $(<8)$ & 86 & 50.6 \\
\hline & Positive ( $\geq 8$ ) & 84 & 49.4 \\
\hline & $8-64$ & 69 & 40.6 \\
\hline & $\geq 64$ & 15 & 8.8 \\
\hline \multirow[t]{2}{*}{ BVDV } & Negative $(<16)$ & 20 & 11.7 \\
\hline & Positive ( $\geq 16$ ) & 151 & 88.3 \\
\hline \multirow[t]{4}{*}{ Leptospira hardjo } & Negative $(<100)$ & 17 & 10.0 \\
\hline & Positive ( $\geq 100$ ) & 153 & 90.0 \\
\hline & $100-200$ & 37 & 21.8 \\
\hline & $\geq 200$ & 116 & 68.2 \\
\hline
\end{tabular}

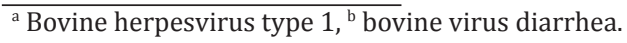

Table 2. Serum neutralization titers against bovine herpesvirus type 1 (BoHV-1) and bovine viral diarrhea virus (BVDV) found by serum agglutination test. Comparison of four studies

\begin{tabular}{ccccc}
\hline Pathogens & Current paper $^{\mathrm{a}}$ & Junqueira et al. (2006) $^{\mathrm{b}}$ & Aono et al. (2013) $^{\mathrm{c}}$ & Pereira et al. (2013) $^{\mathrm{d}}$ \\
\hline BoHV-1 & 49.1 & 81.8 & 68.4 a 49.1 & 100 e 98 \\
BVDV & 81.3 & 98.8 & 68.4 a 49.1 & 52.4 e 49 \\
Leptospirosis & 90.0 & 79.5 & 64.1 a 87.7 & 45.2 e 43
\end{tabular}

Were considered positive samples those range titers $>100$ for leptospirosis, $>8$ for BoHV- 1 and $>16$ for BVDV; ${ }^{\text {a }}$ Titers found in the current paper, ${ }^{\mathrm{b}}$ Titers found in beef cows raised at range in São Paulo, Brazil, ' Titers found in non-vaccinated Girolando beef cows raised at range in Mato Grosso do Sul, Brazil, d Titers found in Girolando beef cows raised at at range in Mato Grosso do Sul, Brazil, and vaccinated against BOHV-1 (one dose) and BVDV (one dose) and leptospirosis (3 doses).

Table 3. Means and standard error of the means of pregnancy or pregnancy loss in cows submitted to IBR/BVDV/Leptospirosis (VACMULT) and Leptospirosis only (VACL) vaccines and non-vaccinated

\begin{tabular}{|c|c|c|c|c|}
\hline Bracket & VACMULT $^{\text {a }}$ & VACL $^{b}$ & NOVAC $^{\mathrm{c}}$ & $p$-value ${ }^{\mathrm{d}}$ \\
\hline P30 e & $56.7 \pm 3.39$ & $47.8 \pm 3.34$ & $53.9 \pm 3.48$ & 0.461 \\
\hline $\mathrm{P} 90^{\mathrm{e}}$ & $59.9 \pm 3.43$ & $52.6 \pm 3.44$ & $54.9 \pm 3.58$ & 0.545 \\
\hline Calving ${ }^{\mathrm{f}}$ & $65.0 \pm 3.30$ & $72.4 \pm 3.02$ & $69.6 \pm 3.30$ & 0.516 \\
\hline 30-to-90-DPI loss ${ }^{\mathrm{g}}$ & $8.6 \pm 2.59$ & $8.2 \pm 2.6$ & $13.5 \pm 3.6$ & 0.251 \\
\hline 30-DPI-to-calving loss ${ }^{\mathrm{h}}$ & $17.5 \pm 2.62$ & $7.76 \pm 1.78$ & $10.4 \pm 2.20$ & 0.298 \\
\hline 90-DPI-to-calving loss ${ }^{\mathrm{i}}$ & $14.5 \pm 2.43$ & $7.4 \pm 1.74$ & $11.2 \pm 2.33$ & 0.384 \\
\hline
\end{tabular}

No significant differences were found for any mean, namely: ${ }^{a}$ Cows vaccinated against BoHV-1, BVDV, and leptospirosis, ${ }^{\mathrm{b}}$ Animals vaccinated against leptospirosis alone, ${ }^{\mathrm{c}}$ Unvaccinated animals, ${ }^{\mathrm{d}} p$-value, vaccination effect, ${ }^{\mathrm{e}}$ Rate of pregnancy at 30 and $90 \mathrm{DPI}, \%$, ${ }^{\mathrm{f}}$ Percentage of calved animals, \%, ${ }^{\mathrm{g}}$ Rate of pregnancy loss from 30 to $90 \mathrm{DPI} \%,{ }^{\mathrm{h}}$ Rate of pregnancy loss from $30 \mathrm{DPI}$ to calving, $\%,{ }^{\mathrm{i}}$ Rate of pregnancy loss from $90 \mathrm{DPI}$ to calving, $\%$.

Table 4. Means and standard error of the means of pregnancies or loss of gestation in cows submitted to IBR/BVDV/Leptospirosis vaccines and only Leptospirosis, comparing different protocols

\begin{tabular}{|c|c|c|c|}
\hline Bracket & $\begin{array}{c}\text { VACGEST }^{\text {a }} \\
\text { (D0 and } 30 \text { DPI) }\end{array}$ & $\begin{array}{l}\text { VACPREV }{ }^{\mathrm{b}} \\
\text { (D0 and D11) }\end{array}$ & $p$-value \\
\hline $\mathrm{P} 30^{\mathrm{c}}$ & $56.4 \pm 3.78$ & $47.9 \pm 3.90$ & 0.357 \\
\hline $\mathrm{P} 90^{\mathrm{c}}$ & $59.8 \pm 3.77$ & $40.6 \pm 3.84$ & 0.174 \\
\hline Calving ${ }^{\mathrm{d}}$ & $80.3 \pm 3.04$ & $70.6 \pm 3.61$ & 0.279 \\
\hline 30-to-90-DPI loss ${ }^{\text {e }}$ & $8.39 \pm 2.16$ & $7.13 \pm 2.02$ & 0.723 \\
\hline 30-DPI-to-calving loss ${ }^{\mathrm{f}}$ & $8.97 \pm 2.21$ & $8.37 \pm 2.19$ & 0.875 \\
\hline 90-DPI-to-calving loss ${ }^{\mathrm{g}}$ & $8.26 \pm 2.15$ & $5.98 \pm 1.85$ & 0.551 \\
\hline
\end{tabular}

No significant differences were found for any mean. ${ }^{a}$ Vaccinated on day zero of FTAI (D0) and again 30 DPI, ${ }^{b}$ Vaccinated on D0 and again on the day of insemination (D11), ${ }^{\text {c }}$ Rate of pregnancy at 30 and 90 DPI, \%, ${ }^{d}$ Percentage of calved animals, \%, ${ }^{\text {e }}$ Rate of pregnancy loss from 30 to 90 DPI, \%, ${ }^{\text {f }}$ Rate of pregnancy loss from 30 DPI to calving, $\%$, ${ }^{g}$ Rate of pregnancy loss from 90 DPI to calving, $\%$. 


\section{DISCUSSION}

The antibody titers found for bovine herpesvirus type-1, BVDV and Leptospira sp. demonstrate that infections occur by these agents in the study herd. The percentages of observed titers (49.41\%, 81.30\% and 90\% respectively) consistent with active infection. High rates of these infections in cattle herds in Brazil are described by other authors (Junqueira et al. 2006, Aono et al. 2013, Pereira et al. 2013) (Table 2).

The studies of the three previously cited authors used the same cutoff point of this study for serological reactions, however herds or sample had different characteristics. The coefficients found by Aono et al. (2013) vary $68.4 \%$ to $49.1 \%$ for BoHV-1, $68.4 \%$ to $49.1 \%$ for BVDV and $64.1 \%$ to $87.7 \%$ for Leptospira sp. It is noteworthy that the cows were vaccinated twice a year against leptospirosis, and samples were collected from different properties. Junqueira et al. (2006) evaluated a herd of beef cattle in São Paulo state, where the reproductive management consisted of artificial insemination and re-mating with bull and found the following prevalence rates: $81.8 \%$ for BoHV-1, 98.9\% for BVDV and 79.5\% for Leptospira sp. In a herd of unvaccinated Girolando cows ( $n=84$ ), Pereira et al. (2013) found seropositivity rates of $100 \%, 52.4 \%$, and $45.2 \%$ for BoHV-1, BVDV and leptospirosis, respectively. For vaccinated cows ( $n=62$ ) for BoHV-1 (one dose), BVDV (one dose), and leptospirosis (three doses) these rates were $98.0 \%, 49.0 \%$, and $43.0 \%$, respectively, indicating that active infection and vaccination yielded similar titers.

The conditions on which this study was conducted, there was no significant difference between groups of vaccinated and unvaccinated cows. The results were independent of nutritional status and of the body condition score of cows. The lack of effect of immunization can be explained by experimental design, which included only multiparous cows, which are exposed to different infectious agents for a longer period of time and therefore possess title protective antibodies or immune larger memory compared to gilts. As previously mentioned active infection and vaccination induces similar titers (Pereira et al. 2013).

Another study in beef cows from MS (Aono et al. 2013) said that vaccination against BoHV-1, BVDV and Leptospira sp. decreased reproductive losses, especially in the category of gilts $(\mathrm{P}<0.03)$. The observations in the multiparous group of cows of the current study are similar to those of other study (Aono et al. 2113) which compared vaccinated and non-vaccinated multiparous beef cows $(n-2,142)$ from different farms. Those authors concluded that gestation rates between pregnancy diagnosis at 30 and 90 days did not differ significantly $(\mathrm{P}<0.43)$ between farms that vaccinated against BoHV-1, BVDV e Leptospira sp. and those that either did no vaccinate or vaccinated only against leptospirosis each six months.

Although the data of the current study suggest the vaccination of primiparous cows reduce economic loss caused by these three diseases in the studied farms, it should be considered that these data cannot be extrapolated to every farm in the state of MS. However, this extrapolation would be valid if the prevalence of active infection in primiparous cows would be high.
In our study, multiparous cows from one single farm, submitted to the same environment with the same husbandry procedures, therefore exposed to the same challenges of pathogens affecting reproduction, demonstrate no significant differences in pregnancy loss between vaccinated and non-vaccinated cows. These data pointed that vaccination is not necessarily husbandry procedure for multiparous cows.

Results of the Experiment 2 of this study showed that vaccination on the day of artificial insemination did not interfere with gestational and two vaccination protocols can be used: VACGEST Protocol (vaccinations at D0 and D30) and VACPREV (vaccinations at D0 and D11) which would facilitate the planning of vaccinations, especially on farms that do not perform the diagnosis of pregnancy 30 days after FTAI. Pregnancy loss rates have proved lower when cows are vaccinated at least 30 days before FTAI, with a second dose at D0 (Aono et al. 2013, Pereira et al. 2013). In lactating beef cows, however, FTAI is typically started 30-45 days post-calving, requiring the initial vaccine dose to be administered in late pregnancy (potentially resulting in miscarriage) or shortly after parturition (with a risk of newborn death as a result of handling) (Antoniassi et al. 2013). Experiment 2 of the present study revealed the feasibility of using two vaccination protocols - namely, VACGEST (vaccination on D0 and at 30 DPI) and VACPREV (vaccination on D0 and D11), which facilitates vaccination planning.

Neither vaccine interfered with the reproductive performance of multiparous cows under the conditions investigated. Protocol VACPREV, with vaccination on D0 and D11, did not differ significantly from protocol VACGEST (the standard protocol for vaccination against reproductive diseases) in primo-vaccinated multiparous cows. The results also demonstrate that the completion of vaccination on the day of artificial insemination does not cause reproductive losses.

Acknowledgements.- This work was funded by the Fundação de Apoio ao Desenvolvimento do Ensino, Ciência e Tecnologia do Estado de Mato Grosso do Sul (Fundect/CNPq, Grant 15/2014, PRONEM/MS, 090/2015) and by the Fundação de Apoio ao Desenvolvimento do Ensino, Ciência e Tecnologia do Estado de Mato Grosso do Sul (Fundect/CNPq, Grant 05/2014, PVMS 003/2015).

\section{REFERENCES}

Antoniassi N.A.B., Juffo G.D., Santos A.S., Pescador C.A., Corbellini L.G. \& Driemeier D. 2013. Causas de aborto bovino diagnosticadas no Setor de Patologia Veterinária da UFRGS de 2003 a 2011. Pesq. Vet. Bras. 33(2):155160. http://dx.doi.org/10.1590/S0100-736X2013000200004.

Aono F.H., Cooke R.F., Alfieri A.A. \& Vasconcelos J.L.M. 2013. Effects of vaccination against reproductive diseases on reproductive performance of beef cows submitted to fixed-timed AI. Theriogenology 79(2):242-248. http://dx.doi.org/10.1016/j.theriogenology.2012.08.008. PMid:23174768.

Corbellini L.G., Pescador C.A., Frantz F., Wunder E., Steffen D.J., Smith D.R. \& Driemeier D. 2006. Diagnostic survey of bovine abortion with special reference to Neospora caninum infection: Importance, repeated abortion and concurrent infection in aborted fetuses in southern Brazil. Vet. J. 172(1):114120. http://dx.doi.org/10.1016/j.tvjl.2005.03.006. PMid:16772136.

Cortese V.S. 2015. Bovine vaccines and herd vaccination programs, p.14651482. In: Smith B.P. (Ed.), Large Animal Internal Medicine. 5th ed. Mosby Elsevier. 
Curran S., Pierson R.A. \& Ginther O.J. 1986. Ultrasonographic appearance of the bovine conceptus from days 20 through 60. J. Am. Vet. Med. Assoc. 189(10):1295-1302. PMid:3793570.

Junqueira J.R.C., Freitas J.C., Alfieri A.F. \& Alfieri A.A. 2006. Avaliação do desempenho reprodutivo de um rebanho bovino de corte naturalmente infectado com BoHV-1, BVDV e Leptospira hardjo. Semina, Ciênc. Agrárias 27(3):471-480. http://dx.doi.org/10.5433/1679-0359.2006v27n3p471.

Pereira M.H., Cooke R.F., Alfieri A.A. \& Vasconcelos J.L. 2013. Effects of vaccination against reproductive on reproductive performance of lactating dairy cows submitted to IA. Anim. Reprod. Sci. 137(3-4):156-162. http:// dx.doi.org/10.1016/j.anireprosci.2012.12.011. PMid:23357089.

Santos J.E.P., Thatcher W.W., Chebel R.C., Cerri R.L.A. \& Galvão K.N. 2004. The effect of embryonic death rates in cattle on the efficacy of estrus syncronization programs. Anim. Reprod. Sci. 82-83:513-535. http://dx.doi. org/10.1016/j.anireprosci.2004.04.015. PMid:15271477.

Wagner J.J., Lusby K.S., Oltjen J.W., Rakestraw J., Wettemann R.P. \& Walters L.E. 1988. Carcass composition in mature Hereford cows: Estimation and effect on daily metabolizable energy requirement during winter. J. Anim. Sci. 66(3):603-612. http://dx.doi.org/10.2527/jas1988.663603x. PMid:3378920. 